\title{
A review of the species of Mesopolobus (Chalcidoidea: Pteromalidae) associated with Ceutorhynchus (Coleoptera: Curculionidae) host-species of European origin
}

\author{
H. Baur ${ }^{1}$, F.J. Muller ${ }^{2}$, G.A.P. Gibson ${ }^{3}$, P.G. Mason ${ }^{3}$ \\ and U. Kuhlmann ${ }^{2 *}$
}

${ }^{1}$ Department of Invertebrates, Natural History Museum, Bernstrasse 15, CH-3005 Bern, Switzerland: ${ }^{2}$ CABI Switzerland Centre, Rue des Grillons 1, 2800 Delémont, Switzerland: ${ }^{3}$ AAFC, Biodiversity (Entomology) and IPM, Research Centre, 960 Carling Avenue, Ottawa, Canada

\begin{abstract}
Four species of Mesopolobus Westwood were reared as parasitoids of Ceutorhynchinae hosts in Europe during surveys in 2000-2004. An illustrated key is given to differentiate the four species, M. gemellus Baur \& Muller sp. n., M. incultus (Walker), M. morys (Walker) and M. trasullus (Walker), plus M. moryoides Gibson, a parasitoid of the cabbage seedpod weevil, Ceutorhynchus obstrictus (Marsham), in North America. Pteromalus clavicornis Walker is recognized as a junior synonym of $M$. incultus syn. $\mathbf{n}$., and Pteromalus berecynthos Walker (also a junior synonym of $M$. incultus) is considered a correct original spelling. For Disema pallipes Förster (a junior synonym of Mesopolobus morys), a lectotype is designated. Mesopolobus morys is for the first time accurately associated with the seed weevil Ceutorhynchus turbatus (Schultze), a potential agent for classical biological control, of hoary cress, Lepidium draba L. (Brassicaceae), in North America. Mesopolobus gemellus is associated with another seed weevil, Ceutorhynchus typhae ( = C. floralis) (Herbst), in pods of shepherd's purse, Capsella bursa-pastoris (L.) Medik. (Brassicaceae). Implications of the host-parasitoid associations are discussed relative to the introduction of species to North America for classical biological control of the cabbage seedpod weevil.
\end{abstract}

Keywords: Mesopolobus, Ceutorhynchus, biological control, non-target effects, new species

\section{Introduction}

In classical biological control concerns regarding potential non-target effects of arthropod biological control agents (Howarth, 1991; Simberloff \& Stiling, 1996; Thomas \& Willis,

*Author for correspondence

Fax: + $41(0) 324214871$

E-mail: u.kuhlmann@cabi.org
1998; Stiling \& Simberloff, 2000; Louda et al., 2003; Stiling, 2004) have led to more studies investigating non-target effects, and efforts have been made to standardize methods for risk assessment studies (Babendreier et al., 2005; Simberloff, 2005; Wright et al., 2005; Kuhlmann et al., 2006a). Understanding the trophic relationships between parasitoids, the target pest species they are aimed at, and potential non-target species is a key requirement prior to any introduction of candidate biological control agents. An important constraint biological control practitioners 
frequently encounter is that the taxonomy of the organisms involved is often unclear (Van Driesche \& Reardon, 2004).

The subfamily, Ceutorhynchinae (Coleoptera: Curculionidae), contains about 1316 species (Colonnelli, 2004), of which some are considered to be herbivorous pests of high economic importance in agricultural crops (Dieckmann, 1972; Mason \& Huber, 2002). A number of Ceutorhynchus species, such as the cabbage seedpod weevil Ceutorhynchus obstrictus (Marsham) (=C. assimilis (Paykull); see Colonnelli (2004)), the cabbage stem weevil Ceutorhynchus napi (Marsham), the cabbage seedstalk curculio Ceutorhynchus pallidactylus (Marsham), and the turnip gall weevil Ceutorhynchus pleurostigma (Marsham) are economically important pests of cruciferous crops. Simultaneously, a number of Ceutorhynchinae species are used worldwide for classical biological control of weeds in crop and non-crop habitats (Julien \& Griffiths, 1998). In North America, Ceutorhynchinae released to reduce the impact of weed species include Mogulones crucifer (Pallas) for houndstongue Cynoglossum officinale (L.) (Boragincaceae) (De Clerck-Floate \& Schwarzlaender, 2002), Hadroplontus litura (Fabricius) for Canada thistle Cirsium arvense (L.) Scopoli (Asteraceae) (McClay et al., 2002a), and Microplontus edentulus (Schultze) for scentless chamomile Tripleurospermum perforatum (Merat) Lainz (Asteraceae) (McClay et al., 2002b). The presence of pests and beneficial agents belonging to the same subfamily adds one level of complexity to the work of biological control practitioners.

The Chalcidoidea (Hymenoptera) contains over 800 different species that have been associated with biological control programmes in one way or another (Noyes, 2006). A number of Mesopolobus (Pteromalidae) species are associated with several Ceutorhynchinae species (Murchie \& Williams, 1998). For instance, Mesopolobus morys (Walker) is one of the most important parasitoids of the cabbage seedpod weevil natural enemy complex in Europe (Williams, 2003). Ceutorhynchus obstrictus is a pest of oilseed rape, Brassica napus L., in Europe and was accidentally introduced in North America where it is now widespread (Kuhlmann et al., 2002). In Canada, C. obstrictus has been recently reported from Alberta (Carcamo et al., 2001), Saskatchewan (Dosdall et al., 2002), Quebec (Brodeur et al., 2001), and Ontario (Mason et al., 2004). As an invasive alien species, C. obstrictus has been a prime target for classical biological control (McLeod, 1962), and several larval ectoparasitoids, including $M$. morys, were released into British Columbia in 1949 (McLeod, 1953). This species was considered to be established in North America until recently when the first follow-up studies were conducted (Gibson et al., 2005, 2006). A review of the parasitoid-C. obstrictus associations in North America determined that reported recoveries of M. morys, after its initial introduction in 1949, were misidentifications of the previously undescribed Mesopolobus (Xenocrepis) moryoides Gibson, which presumably is of North American origin (Gibson et al., 2005). Thus, M. morys, an important natural regulator of C. obstrictus in Europe, is not present in North America. Presently, C. obstrictus is controlled using broad-spectrum chemical insecticides (Dosdall et al., 2001; Carcamo et al., 2005). Classical biological control is being reconsidered with the aim to reduce pesticide use.

The importance of systematics to biological control has been reported previously (Knutson \& Murphy, 1988;
Huber et al., 2002; Bigler et al., 2005). Accurate identification of natural enemies is essential when exotic biological control agents are introduced, especially when morphological variation among species is slight, as in the genus Mesopolobus. For successful biological control of C. obstrictus in North America, it is crucial to clarify the taxonomic status of associated Mesopolobus species because it has: (i) implications for providing accurate ecological baseline data on parasitoid species associated with Ceutorhynchinae hosts in Europe, the area of origin, and (ii) applications towards ensuring safety of classical biological control initiatives.

In this paper, we provide illustrated keys to identify females and males of all European Mesopolobus species known from Ceutorhynchinae hosts. We additionally include the North American species M. moryoides in the keys in case it is eventually discovered in Europe. For our treatment of European species, we include lists of type material and voucher material examined, a comprehensive description of a new species and short diagnoses for females and males of the other recognized species and remarks.

\section{Material and methods}

Material studied is primarily from surveys in Switzerland, Germany, France, Austria, Hungary, Romania and Ukraine during 2000-2004. Specimens 'individually reared' were obtained by dissecting food plants of Ceutorhynchus hosts and then rearing any discovered ectoparasitoid individually to the adult stage. Specimens 'mass collected' were obtained by placing host plants in boxes and collecting parasitoids as they emerged. Adult parasitoids emerged from the boxes into glass vials and were collected, killed, air-dried, pinned, labelled and curated for later identification. All voucher specimens stated as collected by F. Muller, B. Klander, M. Grossrieder and M. Cripps were obtained during the 2000-2004 field surveys and are deposited in the Natural History Museum in Bern, Switzerland (NMBE). Additional material, including type specimens of relevant species, was obtained either from the NMBE or from The Natural History Museum (BMNH) in London, UK.

Descriptions are based on observations made using a Leica MZ16 stereo-microscope coupled to a Leica CLS 150× incandescent light source and with a light diffuser placed over the specimen to reduce the effects of glare. Several images of a specimen were taken through the stereomicroscope at different focal planes using a JVC KY-F70BU triple CCD digital camera and processed using the Syncroscopy Auto-montage ${ }^{\mathrm{TM}}$ software suite. This enabled production of a single, composite, focused image, which allowed us to overcome the problems historically associated with inadequate depth of field for three-dimensional imaging of tiny specimens. Images obtained from the Syncroscopy Auto-montage $^{\mathrm{TM}}$ software suite were retouched using Adobe Photoshop $\mathrm{CS}^{\mathrm{TM}}$ to enhance clarity of the illustrations.

Terms for morphological features and sculpture follow Gibson et al. (1997) and Goulet \& Huber (1993). Terms for colours of various body parts are taken from Graham (1969). Measurements for each species were taken from about 6-10 air-dried specimens, depending on availability. 


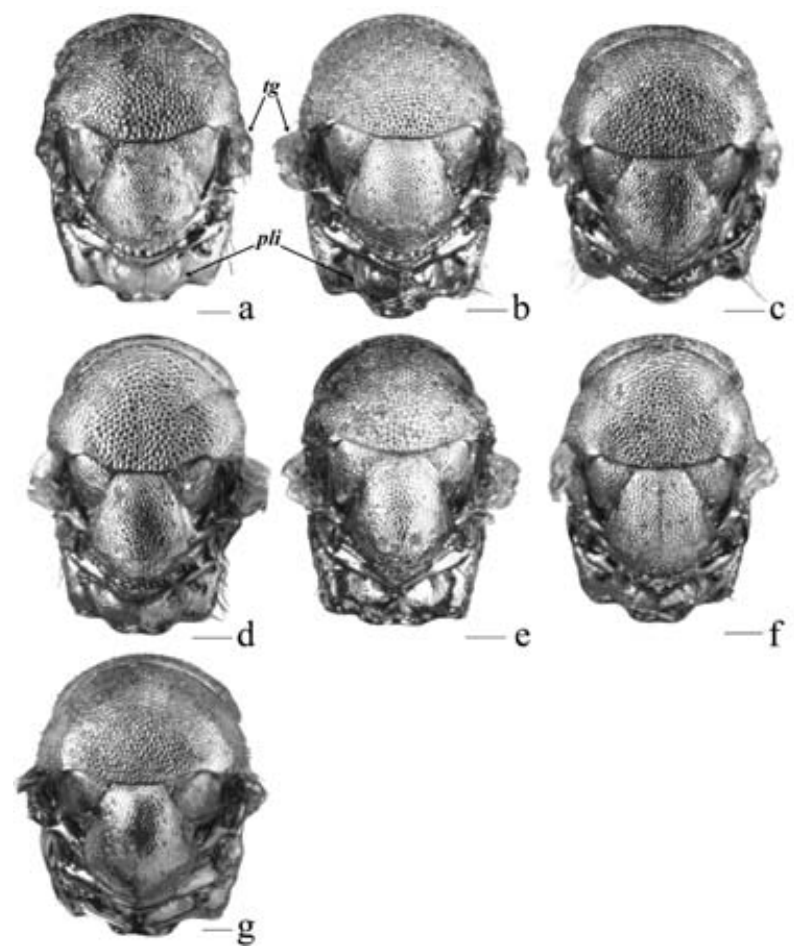

Fig. 1. Mesosoma (dorsal) of (a) q Mesopolobus gemellus Baur \& Muller sp. n.; (b) ㅇ Mesopolobus morys (Walker); (c) ㅇ Mesopolobus incultus (Walker); (d) ô M. gemellus; (e) ô M. morys; (f) ô M. incultus; (g) + Mesopolobus trasullus (Walker). Scale bars $=100 \mu \mathrm{m}$. tg, tegula; pli, plica.

\section{Identification keys \\ Females}

1 Tegula dark (fig. 1g). Clypeus longitudinally strigose (fig. 5d) ......................................................................... 2

- Tegula pale (fig. 1a-c). Clypeus reticulate (fig. 5a-c) . 3

2 Median area of propodeum smooth, plica indicated in posterior third only (Gibson et al., 2005: 389, fig. 16). Fore wing basal fold with at least 2 and often several setae (fig. 4i). Gaster lanceolate (fig. 2d) ... M. trasullus (Walker)

- Median area of propodeum with distinct mesh-like sculpture and plica more or less complete (Gibson et al., 2005: 389, fig. 15). Fore wing basal fold bare. Gaster broader basally, more subcircular (cf. fig. 2a,b)

M. moryoides Gibson [Note: M. moryoides presently known only from North America.]

3 Tip of hypopygium extending two thirds along gaster. Gaster 2.0-2.7× as long as broad (fig. 2c). Pedicel plus flagellum (fig. 3c) about $0.85-0.95 \times$ as long as head breadth ............................................ M. incultus (Walker)

- Tip of hypopygium extending about half way along gaster. Gaster $1.35-1.9 \times$ as long as broad (fig. 2a,b). Pedicel plus flagellum (fig. $3 a, b$ ) about $0.7-0.8 \times$ as long as head breadth

4 Speculum extending about to middle of marginal vein (fig. 4a,b); basal fold with 2-5 setae (fig. 4a,b). Flagellum slightly infuscate (fig. 3a)
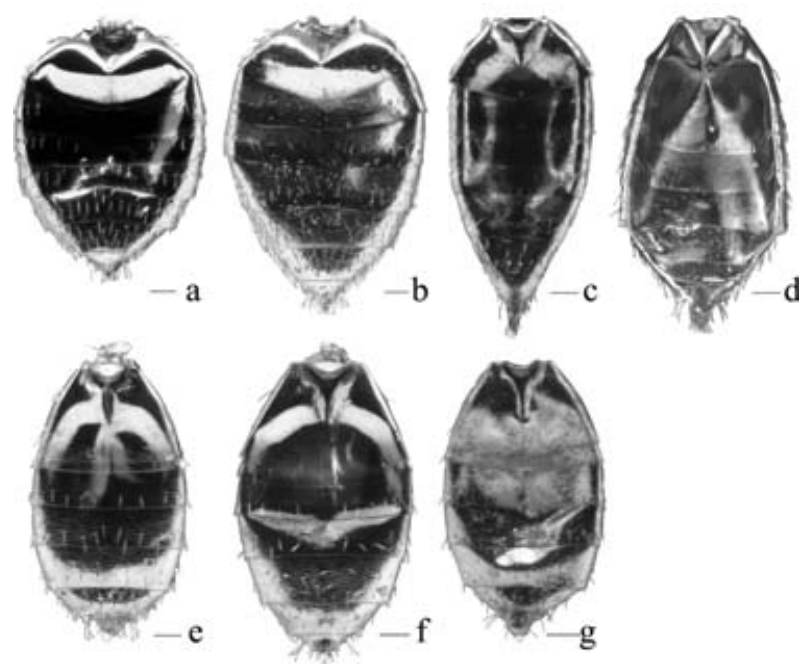

Fig. 2. Gaster (dorsal) of (a) + Mesopolobus gemellus Baur \& Muller sp. n.; (b) ㅇ Mesopolobus morys (Walker); (c) ㅇ Mesopolobus incultus (Walker); (d) o Mesopolobus trasullus (Walker); (e) ô M. gemellus; (f) ô M. morys; (g) ô M. incultus. Scale bars $=100 \mu \mathrm{m}$.

- Speculum extending about to distal end of marginal vein only (fig. $4 \mathrm{~d}, \mathrm{e}$ ); basal fold without or with only 1 seta (fig. 4d,e). Flagellum slightly paler (fig. 3b)

M. morys (Walker)

\section{Males}

1 Fore wing marginal vein inflated, only about $5 \times$ as long as broad (fig. 4f)

- Fore wing marginal vein not inflated, more than $6 \times$ as long as broad (fig. 4c,h)

2 Tegula except sometimes basally, palpi and femora yellow (fig. 6d) ................................... M. morys (Walker)

- Tegula, palpi and all but extreme apices of femora dark ................................................ M. moryoides (Gibson) [Note: M. moryoides presently known only from North America.]

3 Median area of propodeum almost smooth, plica indicated in posterior quarter only (cf. fig. $1 \mathrm{~g}$ ) ................... M. trasullus (Walker)

- Median area of propodeum finely reticulate, plica more or less complete (fig. 1d-f)

4 Head in frontal view 1.21-1.31 times as broad as high (fig. 5a), gena strongly curved ........... M. gemellus sp. n.

- Head in frontal view 1.13-1.18 times as broad as high (fig. 5c), gena rather straight ......... M. incultus (Walker)

\section{Mesopolobus gemellus Baur \& Muller sp. n. (Figs 1a,d, 2a,e, 3a,d, 4a-c, 5a, 6a,b)}

\section{Diagnosis}

Female (fig. 6a). Length: $1.5-2 \mathrm{~mm}$. Flagellum weakly infuscate (fig. 3a). Pedicel plus flagellum about $0.75-0.8 \times$ as long as head breadth. Tegula pale (fig. 1a). Speculum extending, at most, to middle of marginal vein (fig. $4 a, b$ ); basal fold with 


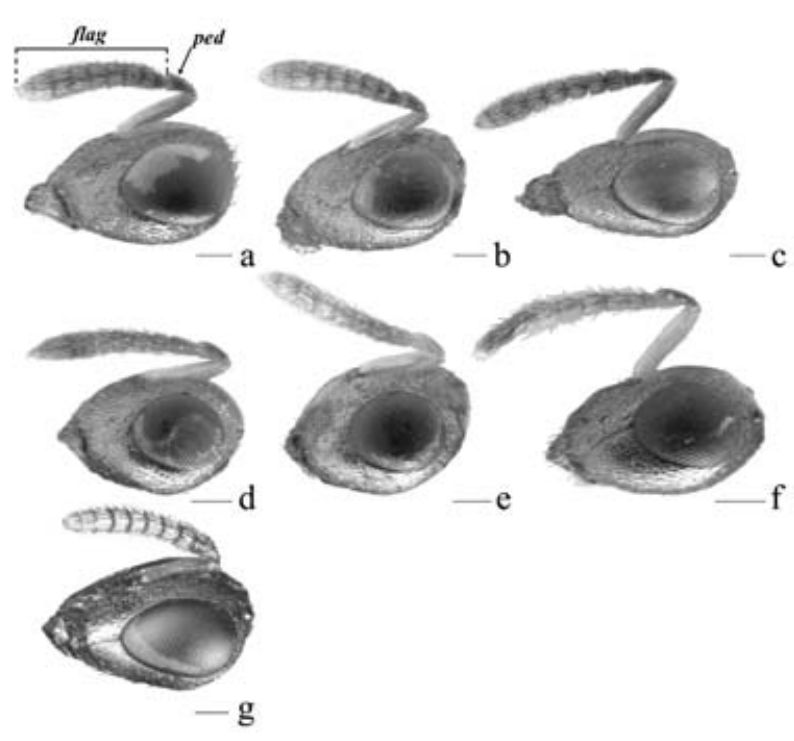

Fig. 3. Head and antennae (front-lateral) of (a) o Mesopolobus gemellus Baur \& Muller sp. n.; (b) + Mesopolobus morys (Walker); (c) + Mesopolobus incultus (Walker); (d) ô M. gemellus; (e) $\hat{o}$ M. morys; (f) ô M. incultus; (g) क Mesopolobus trasullus (Walker). Scale bars $=100 \mu \mathrm{m}$. ped, pedicel; flag, flagellum.

2-5 setae (fig. 4a,b). Median area of propodeum finely reticulate, plica more or less complete. Gaster $1.3-1.6 \times$ as long as broad (fig. 2a); tip of hypopygium reaching about halfway along gaster.

Male (fig. 6b). Length: $1.55-1.85 \mathrm{~mm}$. Head in frontal view $1.21-1.31 \times$ as broad as high (fig. $5 \mathrm{a}$ ) with gena curved; in dorsal view about $1.95-2.05 \times$ as broad as long, occiput rather strongly excavate. Marginal vein more than $6 \times$ as long as broad, not inflated (fig. 4c). Tegula pale (fig. 1d). Median area of propodeum finely reticulate, plica more or less complete. Gaster with indistinct pale spot at base (fig. 2e).

\section{Description}

Holotype male. Length: $1.85 \mathrm{~mm}$. Head bright green with blue tinge in some lights; scape citron yellow; pedicel and flagellum slightly infuscate dorsally, paler below. Mesosoma bright green with bluish tinge. Tegula yellow. Veins light testaceous. Legs with coxae concolorous with body; femora, tibiae, and tarsi citron yellow except for dark apical tarsal segments. Gaster green with indistinct pale spot at base.

Head in dorsal view $1.97 \times$ as broad as long, $1.27 \times$ as broad as high; occiput rather strongly excavate; POL $2.07 \times$ OOL; malar space $0.63 \times$ eye height; eye $1.23 \times$ as high as broad; face finely reticulate, clypeus reticulate with anterior margin truncate. Antenna with lower edge of torulus very slightly above level of lower ocular line; antennal formula 11353; scape not quite extending to ventral margin of anterior ocellus, about $5 \times$ as long as broad and $0.91 \times$ eye height; pedicel in dorsal view $1.8 \times$ as long as broad, slightly longer than anelli plus first funicular segment; combined length of pedicel plus flagellum $0.92 \times$ as long as head breadth; flagellum distinctly clavate; anelli strongly transverse; first funicular segment slightly transverse and distinctly smaller than second segment; second funicular segment slightly longer than broad, fifth transverse; clava $2.1 \times$ as long as broad, slightly shorter than combined length of 3 apical
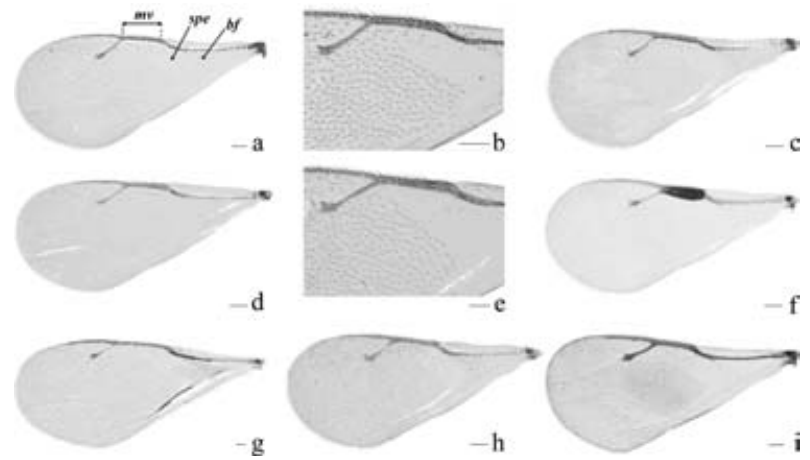

Fig. 4. Fore wings of (a) + Mesopolobus gemellus Baur \& Muller sp. n.; (b) + M. gemellus: detail of speculum; (c) ô M. gemellus; (d) + Mesopolobus morys (Walker); (e) + M. morys: detail of speculum; (f) ô M. morys; (g) o Mesopolobus incultus (Walker); (h) ô M. incultus; (i) O Mesopolobus trasullus (Walker). Scale bars $=100 \mu \mathrm{m}$. bf, basal fold; mv, marginal vein; spe, speculum.

funicular segments (collapsed in holotype), funicular and claval segments with single row of longitudinal sensilla. Mesosoma $1.5 \times$ as long as broad. Pronotal collar differentiated but rounded anteriorly, about one-ninth as long as mesoscutum, reticulate with a smooth strip along posterior margin; mesoscutum $0.6 \times$ as long as broad, finely reticulate with meshes only very slightly smaller in anterior part; scutellum about as long as broad, $0.92 \times$ as long as mesoscutum, finely reticulate with minute meshes along median line and larger meshes on frenum; frenal line indicated laterally; dorsellum alutaceous. Fore wing basal cell with 2 setae, basal setal line lacking; costal cell with complete setal line on lower side, upper side bare; speculum extending to middle of marginal vein, open below; marginal vein about $6.3 \times$ as long as broad, not inflated, $1.33 \times$ as long as stigmal vein and $0.95 \times$ as long as postmarginal vein. Propodeum with superficial but complete plica, median area superficially
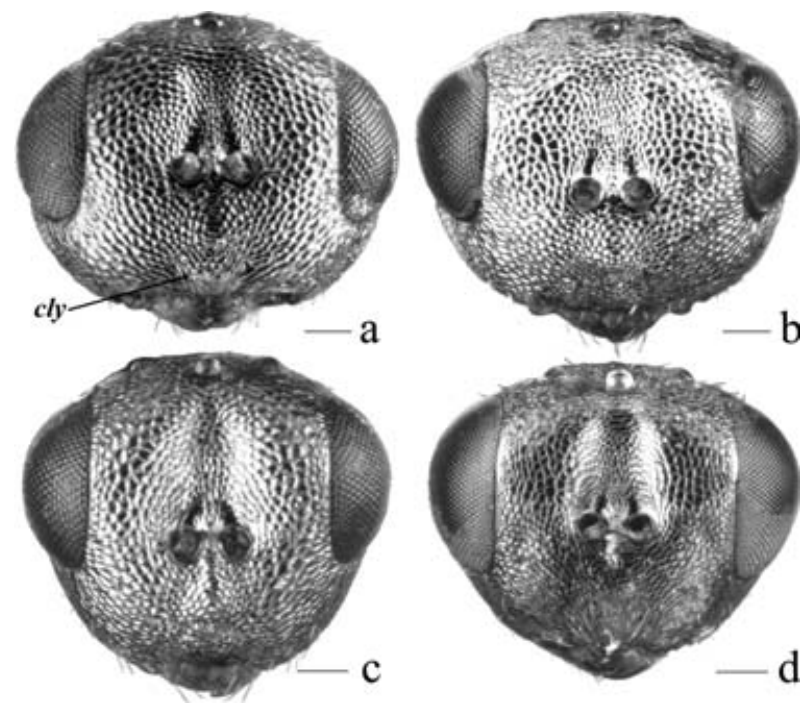

Fig. 5. Head (frontal) of (a) ô Mesopolobus gemellus Baur \& Muller sp. n.; (b) ð̊ Mesopolobus morys (Walker); (c) ô Mesopolobus incultus (Walker); (d) o Mesopolobus trasullus (Walker). Scale bars $=100 \mu \mathrm{m}$. cly, clypeus. 


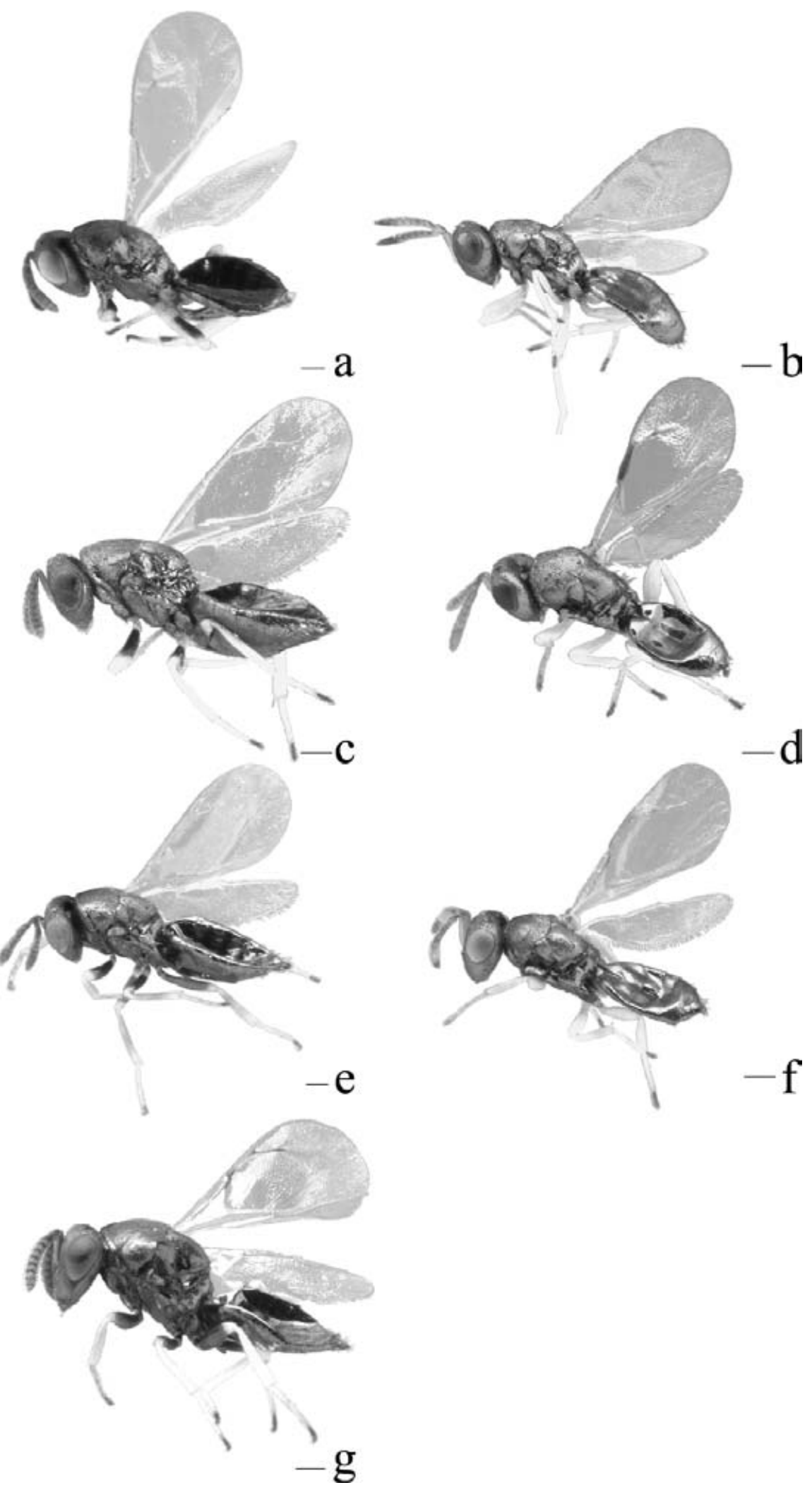

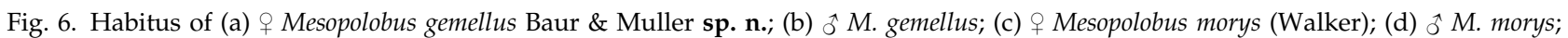
(e) ㅇ Mesopolobus incultus (Walker); (f) ô M. incultus; (g) † Mesopolobus trasullus (Walker). Scale bars = $200 \mu \mathrm{m}$. 
reticulate, $1.7 \times$ as broad as long, $0.47 \times$ as long as scutellum; median carina distinct, straight; nucha angulate medially; spiracular sulcus superficial; right spiracle deformed and tooth-like raised in holotype. Gaster slightly ovate, $1.78 \times$ as long as broad; tergite 1 smooth, tergites 2-6 alutaceous; first tergite occupying two-fifths of length of gaster.

Female (paratype no. 2212) differs from male as follows. Length $1.8 \mathrm{~mm}$. Head bright green to blue green; scape testaceous; pedicel and flagellum infuscate. Femora broadly fuscous in middle. Gaster blue-green. Head in dorsal view more transverse, $2.15 \times$ as broad as long, $1.3 \times$ as broad as high; occiput less strongly excavate; POL $2.3 \times$ OOL; malar space $0.5 \times$ eye height. Antenna with lower edge of torulus inserted distinctly above level of lower ocular line; scape not extending to ventral margin of anterior ocellus, about $4.9 \times$ as long as broad and $0.75 \times$ eye height; pedicel in dorsal view about as long as anelli plus first funicular segment; combined length of pedicel plus flagellum $0.79 \times$ as long as head breadth; first funicular segment about as long as broad and of same size as second. Gaster ovatepointed, $1.57 \times$ as long as broad; first tergite occupying one-third of length of gaster; hypopygium extending to about middle of gaster.

\section{Material examined}

Holotype male labelled: 'ALE 2 coll. 28.VI.2004/61(1) found as larval parasitoid [ink, Muller's hand]; Alle/ALE2 Jura (Ajoie)/Switzerland GPS lat. N47.436608 long. E07.141965 [print]; Ex.: Ceuto. floralis in: C. bursa-pastoris leg. F. Muller/ CABI-CH [print]; Holotype ô Mesopolobus gemellus sp. n. det. Baur \& Muller 2005 [ink, Baur's hand; label with red left and right margin]'.

Paratypes: CZECH REPUBLIC: Bohemia, Holovousy, coll. 26.vii.1953; leg. Hostounsky (1ㅇ) (BMNH). ENGLAND: Middlesex, Hampton, coll. 8.vi.1964; leg. Bouček (1ㅇ) (BMNH). GERMANY: Ostholstein, Nähtkampf, coll. 14.vi.2000; leg. B. Klander; indiv. reared from larval parasitoids, ex Ceutorhynchus typhae (Herbst) (=C. floralis) in fruits of Capsella bursa-pastoris (L.) Medik. (17̧人; 15ㅇ). Schleswig-Holstein, Kiel, Scharnhagen, coll. 16-22.vi.2001; leg. B. Klander; indiv. reared from larval parasitoids, ex C. typhae (=C. floralis) in fruits of C. bursa-pastoris (14ð; 25우). SWITZERLAND: Canton Jura, Alle, Les Genavrats, $490 \mathrm{~m}$, N47 $26^{\prime} 11.79^{\prime \prime}$ E7 $8^{\prime} 31.07^{\prime \prime}$, 28.vi.2004, leg. F. Muller, ex C. typhae in fruits of C. bursa-pastoris $(23 \hat{0} ; 15$ ㅇ). Mass collected material from various sites in: FRANCE: Alsace, Faverois, FAV, N47 $31^{\prime} 8.21^{\prime \prime}$ E7 ${ }^{\circ} 3^{\prime} 11.94^{\prime \prime}$ \& SWITZERLAND: Valais, valley from Martigny to Sion; coll. 9-29. vi. 2004; leg. F. Muller; mass collected adults emerged from pods of C. bursapastoris placed in emergence boxes $(33 \hat{\jmath} ; 25 \circ$, incl. paratype

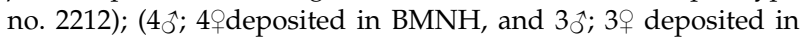
Askew collection).

Other material: SWITZERLAND: Valais, Martigny, N46 $6^{\prime} 36.49^{\prime \prime}$ E7 $^{\circ} 6^{\prime} 12.82^{\prime \prime}$; coll. 29.VI.2004; leg. F. Muller, ex Ceutorhynchus turbatus Schulze in fruits of Lepidium draba L. (1ㅇ).

\section{Etymology}

The specific name 'gemellus', meaning twin in latin, refers to the similarity of this species with $M$. morys. The name is treated as a noun in apposition, which is why agreement in gender with the generic name is not needed.

\section{Comments}

The male of $M$. gemellus sp. $\mathrm{n}$. is readily separated from all other Mesopolobus species treated here by the combination of characters given in the key and the diagnosis. However, the female is very similar to $M$. morys, from which it can only be separated by the slightly reduced fore wing speculum and greater number of setae on the basal fold. Because the male sex is much more distinct, a male was chosen for the holotype. The female reared from Ceutorhynchus turbatus on Lepidium draba fits the type series quite well, except for a slightly longer gaster (1.92× as long as broad), and for this reason it was not included in the type series.

\section{Mesopolobus incultus (Walker) \\ (Figs 1c,f, 2c, g, 3c,f, 4g,h, 5c, 6e,f)}

Platyterma incultum Walker, 1834: 340, lectotype male in BMNH (B.M. TYPE HYM. 5.1864), designated by Graham (1957: 229) (examined by Baur).

Platyterma femorale Walker, 1834: 341-342, lectotype female in BMNH (B.M. TYPE HYM. 5.1865), designated by Graham (1957: 229) (examined by Baur). This specimen has the values of two ratios slightly below the range of variation we determined for other $M$. incultus: combined length of pedicel plus flagellum to head breadth (0.83) and length to breadth of gaster (1.86). Furthermore, the lower side of the gaster is hidden and thus the extension of the hypopygium, another diagnostic character, could not be examined. However, the straight and relatively long gena leaves no doubt concerning the identity of the specimen.

Amblymerus stupidus Walker, 1834: 348-349, lectotype female in BMNH (B.M. TYPE HYM. 5.1866), designated by Graham (1957: 229) (examined by Baur).

Pteromalus leodocus Walker, 1839: 237, lectotype male in BMNH (B.M. TYPE HYM. 5.1868), designated by Graham (1957: 229) (examined by Baur).

Pteromalus ergias Walker, 1839: 238, lectotype male in BMNH (B.M. TYPE HYM. 5.1869), designated by Graham (1957: 229) (examined by Baur).

Pteromalus amyntor Walker, 1845: 263, lectotype female in BMNH (B.M. TYPE HYM. 5.1870), designated by Graham (1957: 229) (examined by Baur).

Pteromalus urgo Walker, 1845: 263, lectotype female in BMNH (B.M. TYPE HYM. 5.1871), designated by Graham (1957: 229) (examined by Baur).

Pteromalus belesis Walker, 1848: 125, 189, lectotype male in BMNH (B.M. TYPE HYM. 5.1872), designated by Graham (1957: 229) (examined by Baur).

Pteromalus berecynthos Walker, 1848: 125, 190, lectotype male in BMNH (B.M. TYPE HYM. 5.1873), designated by Graham (1957: 229) (examined by Baur). The specific name was actually misspelled by Walker (1848: 125) as 'berycynthos', which had gone unnoticed by Graham $(1957,1969)$ and Noyes $(2006)$. We here chose the alternative spelling 'berecynthos', on page 190, as the correct original spelling, which is also linguistically correct (from 'Berecynthes', the latin name for an ancient Phrygian people). Pteromalus lissos Walker, 1848: 125, 196, lectotype male in BMNH (B.M. TYPE HYM. 5.1874), designated by Graham (1957: 229) (examined by Baur).

Pteromalus clavicornis Walker, 1874: 318, holotype female in BMNH (B.M. TYPE HYM. 5.726) (examined by Baur), syn. n. Reexamination of the holotype confirmed the tentative synonymy suggested by Graham (1969: 654).

Eutelus (Amblymerus) crassicornis Thomson, 1878: 80-81, lectotype female (type number 264:1) in Lund University, Zoological Museum, Lund (Sweden), designated by Graham (1957: 230) (examined by Baur). 


\section{Diagnosis}

Female (fig. 6e). Length: 1.5-2.4 mm. Flagellum infuscate (fig. 3c). Pedicel plus flagellum about $0.85-0.95 \times$ as long as head breadth. Tegula pale (fig. 1c). Speculum extending to proximal quarter or distal end of marginal vein (fig. $4 \mathrm{~g}$ ); basal fold with $0-5$ setae, sometimes with additional 1-3 setae in distal part of basal cell. Median area of propodeum finely reticulate, plica more or less complete. Gaster $2.0-2.7 \times$ as long as broad (fig. 2c); tip of hypopygium reaching about two-thirds along gaster.

Male (fig. 6f). Length: $1.4-1.8 \mathrm{~mm}$. Head in frontal view 1.13$1.18 \times$ as broad as high (fig. 5c) with gena rather straight; in dorsal view about $2.2 \times$ as broad as long, occiput rather strongly excavate. Marginal vein not inflated, more than $6 \times$ as long as broad (fig. 4h). Tegula pale (fig. 1f). Median area of propodeum finely reticulate, plica more or less complete. Gaster without pale spot medially (fig. 2g).

\section{Material examined}

GERMANY: Ostholstein, Nähtkamp, coll. 14.vi.2000; leg. B. Klander; indiv. reared ex Capsella bursa-pastoris (1ㅇ). ITALY: Novara, Antronaplana, V. Loranco, W.Rif Andolla, 648.1/105.0, 2300m.; coll. 6.viii.1992; leg. H. Baur (NMBE); collected by sweeping (39); Lago d'Orta, 678.72.4, 310m.; coll. 24.vi.1993; leg. H. Baur (NMBE); collected by sweeping (2+). MOROCCO: Talasoltane, Rif. 1850m.; Coll. 4-11.vii.1961; leg. V. Delucchi (NMBE); collected by sweeping (4ㅇ). SWEDEN: Akarp, coll. 4.vii.1961; leg. H. Von Rosen (NMBE); collected by sweep-

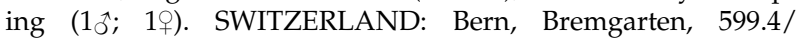
202.9,550M.; coll. 12.v-18.vii.1992; leg. H. Baur (NMBE); collected by sweeping (6\%); Diemtigen, SW Griemialp, 602.9/ 157.1, 1240m.; coll. 9.vi.1992; leg. H. Baur (NMBE); collected by sweeping (19); Eymatt, 596.7/201.45, 510m.; coll. 20.v.2004; leg. H. Baur (NMBE); collected by sweeping (1ㅇ); Kandersteg, Undere Allme, 616.025/149.175, 1790m.; coll. 28.viii.1991; leg. H. Baur (NMBE); collected by sweeping (3ㅇ); Ruemendingen, 614.9/217.5, 510m.; coll. 26.v.1992; leg. H. Baur (NMBE); collected by sweeping (19); Vauffelin, 591/226, 720m.; coll. 16.vii.1996; leg. H. Baur (NMBE); collected by sweeping (1ㅇ); Wohlen b. B., Schürhubel, 588.9/202.35, 520m.; coll.14.v.1992; leg. H. Baur (NMBE); collected by sweeping (3); Neuchatel, La Brévine, SW Le Maix Rochat, 539.4/205.0, 1050m.; coll. 3-10.viii.1992; leg. C. Vaucher (NMBE); collected by sweeping (19); Valais, Bitsch, Schwarzes-Flesh, 643.3/133.25, 1620m.; coll. 17.viii.1992; leg. H. Baur (NMBE); collected by sweeping (19); Ferden, Torbu, 623.55/138.7, 2010m.; coll. 2.viii.2003; leg. H. Baur (NMBE); collected by sweeping (19); Gryon, SE La Chaux, 574.5/126.85, 1720m.; coll. 29.vi.2003; leg. H. Baur (NMBE); collected by sweeping (19); Gryon, Frience, 574.4/ 126.4, 1550m; coll. 29.vi.2003; leg. H. Baur (NMBE); collected by sweeping (1ㅇ); NE Hohtenn, 625.65/130.75, 1460m.; coll. 30.vi.1992; leg. H. Baur (NMBE); collected by sweeping (3 3 ; 2); Vaud, Burlignère, Le Chenit, 502.3/156.8, 1050m.; coll. 17-24vii.1994; leg. C. Vaucher (NMBE); collected by sweeping (19); Zurich, Maschwanden, Rüss-Spiez-Ried, 388m.; coll. 21.viii.1989; leg. Rezbanyai-reser (NMBE); collected by sweeping (1ㅇ);

\section{Comments}

The male of M. incultus is most similar to M. gemellus sp. n., but is separated by a less transverse head in frontal view (see fig. 5a,c). From the female of both M. gemellus and M. morys, it is differentiated by a longer flagellum and gaster, and the hypopygium extending about two-thirds along the gaster. Furthermore, the gena of $M$. incultus is straighter and relatively longer. In contrast to $M$. gemellus and M. morys, the extension of the fore wing speculum varies considerably in females of $M$. incultus. In some specimens, it extends only to the proximal quarter of the marginal vein, whereas in others it extends to the beginning of the stigmal vein. Because certain individuals show intermediate states (for instance 19 from Valais, Gryon, SE of La Chaux) and the specimens are otherwise indistinguishable, we assume that only one species is involved.

\section{Mesopolobus morys (Walker) \\ (Figs $1 b, e, 2 b, f, 3 b, e, 4 d-f, 5 f, 6 c, d$ )}

Pteromalus morys Walker, 1848: 125, 197, lectotype male in BMNH (B.M. TYPE HYM. 5.1879), designated by Graham (1957: 235) (examined by Baur).

Encyrtus ceutorhynchi Rondani, 1872: 207, lectotype female in Zoological Museum 'La Specola' in Florence (Italy), designated by Bouček (1974: 247) (examined by Baur).

Disema pallipes Förster, 1878: 54, lectotype male (mounted with a micro-pin on a small pith block; left metatarsus lacking, right flagellum and wings partly damaged by pest insects, e.g. marginal vein of left fore wing lacking; specimen otherwise entire) in Museum für Naturkunde, Humboldt Universität, Berlin (Germany) labelled '17 [hand]/198. [print]; Frst [print]; Det. S. Novickij [sic, print] Xenocrepis pura Mayr ô [pencil, Novicky's hand]; Lectotype đ̊ Disema pallipes Förster, 1878 des. H. Baur 2006 [ink, Baur's hand; label with red left and right margin]', synonymized with M. morys by Rosen (1961: 32-33) (examined by Baur). Rosen examined this specimen, but he did not designate it lectotype. Because Förster did not specify the number of specimens he had, we regard it only as a syntype which is here designated lectotype. It fits the original description well, except that Förster mentioned only two anelli instead of three. However, the first anellus is hardly discernible in the lectotype, even with a modern stereo-microscope; hence he may simply have overlooked it. According to the original description, the material was collected in Switzerland ('Aus der Schweiz.') and not in Germany, as stated by Noyes (2006).

Disema pallidipes Dalla Torre, 1898: 201, unjustified emendation of D. pallipes Förster.

Xenocrepis pura Mayr, 1904: 584-586, holotype male, synonymized with M. morys by Graham (1957: 235). Mayr (1904: 586) described a single specimen which was collected by Förster near Aachen (Germany). According to Graham (1969: 654) the holotype should be in the Natural History Museum, Vienna (Austria). Manuala Vizek, curator of Hymenoptera in Vienna, kindly informed us that the holotype is not traceable in their collection. However, the detailed description by Mayr (1904) leaves no doubt concerning the identity of the species.

\section{Diagnosis}

Female (fig. 6c). Length: $1.6-2.5 \mathrm{~mm}$. Flagellum weakly infuscate (fig. 3b). Pedicel plus flagellum about $0.7-0.8 \times$ as long as head breadth. Tegula pale (fig. 1b). Speculum extending to distal end of marginal vein (fig. $4 \mathrm{~d}, \mathrm{e}$ ); basal fold with 0 1 seta. Median area of propodeum finely reticulate, plica more or less complete. Gaster $1.4-1.9 \times$ as long as broad (fig. 2b); tip of hypopygium reaching about halfway along gaster.

Male (fig. 6d). Length: 1.4-2.1 mm. Head in frontal view 1.22$1.33 \times$ as broad as high with gena curved (fig. $5 b$ ); in dorsal view 
about $2 \times$ as broad as long, occiput weakly excavate. Marginal vein inflated and only about $4.5 \times$ as long as broad (fig. $4 \mathrm{f}$ ). Tegula pale (fig. 1e). Median area of propodeum finely reticulate, plica more or less complete. Gaster without pale spot medially (fig. 2f).

\section{Material examined}

FRANCE: Alsace, Boron, BRN3, N47 $32^{\prime} 11.34^{\prime \prime}$ E7 $0^{\prime} 24.09^{\prime \prime}$; coll. 21.vi.2004; leg. F. Muller, indiv. reared from larval parasitoids, ex. Ceutorhynchus obstrictus in pods of Brassica napus (1ㅇ). Faverois, FAV, N47 $31^{\prime} 8.21^{\prime \prime} \mathrm{E}^{\circ} 3^{\prime} 11.94^{\prime \prime}$; coll. 6.vii.2004; leg. F. Muller; mass. coll, ex. C. obstrictus in pods of B. napus (7今; 3ㅇ); coll. 28.vi.2004; Leg F. Muller; indiv. reared from larval parasitoids, ex. C. obstrictus in pods of B. napus $(3 \hat{3} ; 5$ ㅇ). GERMANY: Schleswig-Holstein, Rastorfer Passau, RP, N54 ${ }^{\circ} 16^{\prime} 58.80^{\prime \prime} \quad \mathrm{E} 10^{\circ} 20^{\prime} 60.00^{\prime \prime}$; coll. 24-28.vi.2002 \& 1.vii.2002; leg. F. Muller; indiv. reared from larval parasitoids, ex. C. obstrictus in pods of $B$. napus $\left(4{ }^{*} ; 1\right.$ i $)$. SWITZERLAND: Jura, Chatillon, La Prîre CHA1, N47 $20^{\prime} 3.43^{\prime \prime}$ E7 $7^{\circ} 9^{\prime} 56.28^{\prime \prime}$; coll. 927.vi.2002 \& 01.vii.2002; leg. F. Muller; indiv. reared from larval parasitoids, ex. C. obstrictus in pods of B. napus (21; 179); CHA-LP2; coll. 9-26.vi.2002, em. 23-27.vi.2003 \& 112.vii.2002; Leg. F. Muller; indiv. reared from larval parasitoids, ex. C. obstrictus in pods of B. napus $(7 \hat{\jmath} ; 6$ ? $)$; coll. 1022.vi.2003, em. 16.vi-27.vii.2003; Leg. F. Muller, indiv. reared from larval parasitoids, ex. C. obstrictus in pods of B. napus (153) 32ㅇ); CHA-LP3; coll. 10-25.vi.2002, em. 25-27.vi.2003 \& 1-20.vii.2002; Leg. F. Muller, indiv. reared from larval parasitoids, ex. C. obstrictus in pods of B. napus $(9 ;$; 14 ); Coeuve, COE1, N47 $27^{\prime} 55.00^{\prime \prime}$ E7 $6^{\prime} 40.01^{\prime \prime}$; coll. 21.vi.2004; leg. F. Muller, indiv. reared from Larval parasitoids, ex. C. obstrictus in pods of $B$. napus (1今); Courrendlin, COUR1, N47 $20^{\prime} 47.55^{\prime \prime}$ E7 ${ }^{\circ} 17^{\prime} 36.21^{\prime \prime}$; coll. 15.vi.2004; leg. F. Muller; indiv. reared from larval parasitoids, ex. C. obstrictus in pods of B. napus $(1 \hat{0} ; 1$ 우); Courroux, CRX11, N47²2' 1.64" E7 22' 3.90"; coll. 21.vi.2004; leg. F. Muller; indiv. reared from larval parasitoids, ex. C. obstrictus in pods of $B$. napus $(2 \hat{\zeta} ; 1$ ) $)$; Delémont, Le Chavelier DEL-DOM; coll. 10-20.vi.2003, em. 21.vi-11.vii.2003; Leg. F. Muller; indiv. reared from larval parasitoids, ex. C. obstrictus in pods of B. napus $\left(11 \hat{\delta^{*}} ; 22\right.$ ) ; Valais, Martigny, MAR1A, N466 6 25.60" E7 4' 19.33"; coll. 29.vi.2004 \& 5.vii.2004; Leg. F. Muller; indiv. reared from larval parasitoids, ex Ceutorhynchus turbatus in pods of Lepidium draba (9); 4). MAR2, N46 $6^{\prime} 47.04^{\prime \prime}$ E7 $6^{\prime}$ 54.24"; coll. 15.vi-5.vii.2004; Leg. F. Muller; indiv. reared from larval parasitoids, ex C. turbatus in pods of L. draba (7今; ;1 19). Ecône-Riddes, VS-Eco, N46 ${ }^{\circ} 10^{\prime} 28.87^{\prime \prime}$ E7 ${ }^{\circ} 2^{\prime}$ 54.19"'; coll. 17.vi.2004, em. 3.vii.2003; Leg. F. Muller; indiv. reared from larval parasitoids, ex C. turbatus in pods of L. draba (2)); Saxon, VS-Sax; coll. 17\&22.vi.2004, em. 27.vi11.vii.2003; Leg. F. Muller; indiv. reared from larval parasitoids, ex C. turbatus in pods of L. draba (14 3 ; 20ㅇ); Sion, SIN11, N46 $13^{\prime} 11.80^{\prime \prime} \mathrm{E}^{\circ} 20^{\prime} 43.09^{\prime \prime}$; coll. 29.vi.2004 \& 5.vii.2004; Leg. F. Muller; indiv. reared from larval parasitoids, ex C. turbatus in pods of L. draba (14); 7\%); Sion VS-SW1; coll. 17\&22.vi.2004, em. 3-11.vii.2003; Leg. F. Muller; indiv. reared from larval parasitoids, ex C. turbatus in pods of L. draba $(2 \hat{0} ; 2$ 우). HUNGARY: Csongrad, Lep-HU36, N46 $24^{\prime} 50.80^{\prime \prime}$ E20 $0^{\prime} 3.24^{\prime \prime}$; coll. 24.vi-11.vii.2004; Leg. F. Muller; indiv. reared from larval parasitoids, ex C. turbatus in pods of L. draba $\left(8 \beta^{*} ; 6\right.$ ); Hödmezövazarhely, Lep-HU61, N46 15' 41.62" E20 $12^{\prime} 24.52^{\prime \prime}$; coll. 22.vi-11.vii.2004; leg. F. Muller; indiv. reared from larval parasitoids, ex C. turbatus in pods of L. draba $(4 \hat{0} ; 4$ 우). Pest, Apaj, Lep-HU65, N47 ${ }^{\circ} 12^{\prime} 9.12^{\prime \prime}$ E19 $13^{\prime}$ 50.22" ; coll. 24.vi.2004 \& 11.vii.2004; leg. F. Muller; indiv. reared from larval parasitoids, ex C. turbatus in pods of L. draba $(1 \hat{\delta} ; 1$ 우). Kiskunlachaza, LepHU66, N47 $11^{\prime} 48.19^{\prime \prime}$ E19 $6^{\prime} 36.40^{\prime \prime}$; coll. 19.vi.2004; Leg. F. Muller; indiv. reared from larval parasitoids, ex C. turbatus in pods of L. draba (1今). Budapest, Lep-HU7B, N47 $12^{\prime} 30.24^{\prime \prime}$ E19 ${ }^{\circ} 3^{\prime}$ 6.06" ; coll. 30.vi.2004 \& 11.vii.2004; leg. F. Muller; indiv. reared from larval parasitoids, ex C. turbatus in pods of L. draba (2ङ).

\section{Comments}

The male of M. morys is readily distinguished from other European species of Mesopolobus by its inflated marginal vein (fig. 4f), and the colour differences given in the key easily differentiate it from $M$. moryoides. However, the female is very close to M. gemellus sp. nov., as is discussed under the latter species.

\section{Mesopolobus trasullus (Walker)}

(Figs $1 g, 2 d, 3 g, 4 i, 5 d, 6 g$ )

Ormocerus trasullus Walker, 1839: 207, lectotype female in BMNH (B.M. TYPE HYM. 5.1867), designated by Graham (1957: 229) (examined by Baur and Gibson).

Mesopolobus roseni Graham, 1984: 512-513, holotype female in BMNH (B.M. TYPE HYM. 5.3028) (examined by Baur and Gibson).

\section{Diagnosis}

Female (fig. 6g). Length: $2.1-2.3 \mathrm{~mm}$. Flagellum yellowishbrown to brown, sometimes slightly paler on lower side (fig. 3g). Pedicel plus flagellum about $0.4-0.8 \times$ as long as head breadth. Tegula brown (fig. 1g). Speculum extending from about basal quarter to middle of marginal vein (fig. 4i); basal fold with 2-7 setae. Median area of propodeum smooth and shiny, plica indicated in posterior quarter to third only. Gaster $1.7-2 \times$ as long as broad (fig. $2 \mathrm{~d}$ ); tip of hypopygium reaching, at most, slightly more than halfway along gaster.

Male. Length: $1.1-1.7 \mathrm{~mm}$. Head in frontal view about $1.2 \times$ as broad as high with gena slightly curved; in dorsal view about $2.15-2.2 \times$ as broad as long, occiput moderately strongly excavate. Marginal vein not inflated, more than $6 \times$ as long as broad. Tegula yellow to brown. Median area of propodeum feebly alutaceous, plica indicated in posterior quarter only. Gaster with a large testaceous spot basally on ventral side, hence basal half of dorsal side appears slightly paler than apical half.

\section{Material examined}

CZECH REPUBLIC: Bohemia, Praha-Butovice, Prokopskè Udoli, lat. N5002.609" long. E014 21.348', 100m; coll. 7.vi.2004; leg. H. Baur (NMBE); collected by sweeping (1ㅇ). Koda u Berouna; coll. 17.v.1953; leg. Z. Bouček (BMNH) (1ㅇ); Hor. Lipka-Králic, Sneznik; coll. 16.viii.1962; leg. Z. Bouček (BMNH) (1). ITALY: South Sardinia, Villasimius; coll. vi.1975; leg. Z. Bouček (BMNH) $(1 \hat{\jmath}, 1$ i $)$. SPAIN: Zaragoza, Retuerta de Pina, 10.ix.1992; leg. J. Blasco-Zumeta, swept from Gypsophila hispanica Willk. [Caryophyllaceae] $(2 \hat{\jmath}, 4+9)$. SWITZERLAND: Basel, Bottmingen; coll. 22.vii.1935; leg. W. Wittmer (NMBE) (1ㅇ).

\section{Comments}

Gibson \& Baur (2005) pointed out that M. trasullus was erroneously synonymized under M. incultus by Graham (1957) and recognized it as the senior synonym of Mesopolobus roseni. Because only three males of this species were available for 
study, the characters given in the key and the diagnosis are partly based on the description by Askew et al. (2001).

\section{Discussion}

Results of this study provide a basis for accurate Mesopolobus spp.-Ceutorhynchinae host associations in Europe, which is essential for a renewed classical biological control initiative against C. obstrictus in North America. In this context, it was documented that the previously undescribed M. gemellus, and not M. morys (as previously reported by Klander, (2001)), parasitizes $C$. typhae $(=C$. floralis) in Europe. Furthermore, $M$. morys is for the first time accurately associated with the seed weevil $C$. turbatus, a potential agent for classical biological control of hoary cress, Lepidium draba, in North America. This information is of significant interest to the scientific community involved in the classical biological control of C. obstrictus in North America (Kuhlmann et al., 2006b) because biological control practioners now have to assess potential non-target impacts of invertebrate biological control agents to justify their release.

It should be noted that, in general, an understanding of the population dynamics of Ceutorhynchinae species of economic importance is still hampered by insufficient knowledge of natural enemy complexes that may play an important role in regulating these herbivorous insects (Vidal, 2003). The clarification of the taxonomy of the Mesopolobus species presented here provides a sound basis for understanding these dynamics, leading towards the safe use of Mesopolobus species against Ceutorhynchinae pest species.

\section{Acknowledgements}

The authors acknowledge Emmanuel Cuenot (France), Virginia Larraz (Spain), Leonore Lovis (Switzerland), Gabor Nagy (Hungary), Fezekas Janos (Hungary), Alicia Leroux (Canada), Tara Gariepy (Canada), Kim Riley (Canada), Lars Andreassen (Canada), Leyla Valdivia Buitriago (Peru), Rike Stelkens (Germany) and Stephen Maggins (Ireland) for their valuable help as part of the CABI Agricultural Pest Research dissection team, and also thank Maren Belde (Technische Universität, Munich, Germany) and Beate Klander (Christian Albrechst Universtity, Kiel, Germany) for finding collection sites of Canada thistle in Germany. Dr. Scheibelreiter (Wien, Austria) assisted with collections of scentless chamomile in Austria in 2003. The authors appreciated the fruitful discussions with André Gassmann, Hariet Hinz, Stefan Toepfer and Esther Gerber (all CABI, Delémont) and acknowledge them as well for information exchanged on collection sites of scentless chamomile, hoary cress, Canada thistle, garlic mustard and other Ceutorhynchinae host plants in various European countries. This work was funded by Agriculture and Agri-Food Canada, AAFC's Pest Management Research Centre Project PRR03-370, and the Alberta Agricultural Research Institute. Technical support was provided by the Natural History Museum at Bern, Switzerland. For the loan of and information on specimens, the authors are grateful to: Richard R. Askew, Beeston, Tarporley (UK); Luca Bartolozzi, Zoological Museum 'La Specola', Florence (Italy); Roy Danielsson, Lund University, Zoological Museum, Lund (Sweden); Frank Koch, Museum für Naturkunde, Humboldt-Universität Berlin, Berlin (Germany); Andreas Muller, Institute for Plant Science, Swiss Federal Institute of Technology, Zürich (Switzerland); John S. Noyes, The Natural History Museum, London (UK); and Manuela Vizek, Natural History Museum, Vienna (Austria).

\section{References}

Askew, R.R., Blasco-Zumeta, J. \& Pujade-Villar, J. (2001) Chalcidoidea and Mymarommatoidea (Hymenoptera) of a Juniperus thurifera L. forest of Los Monegros region, Zaragosa. Monografias Sociedad Entomológica Aragonesa 4, $5-76$.

Babendreier, D., Bigler, F. \& Kuhlmann, U. (2005) Methods used to assess non-target effects of invertebrate biological control agents of arthropod pests. BioControl 50 (6), 821-870.

Bigler, F., Baleb, J.S., Cock, M.J.W., Dreyer, H., Greatrex, R., Kuhlmann, U., Loomans, A.J.M. \& Van Lenteren, J.C. (2005) Guidelines on information requirements for import and release of invertebrate biological control agents in European countries. CAB Reviews: Perspectives in Agriculture, Veterinary Science, Nutrition and Natural Resources 1 (001), 1-10.

Bouček, Z. (1974) On the Chalcidoidea (Hymenoptera) described by C. Rondani. Redia 55, 241-285.

Brodeur, J., Leclerc, L., Fournier, M. \& Roy, M. (2001) The cabbage seedpod weevil, Ceutorhynchus obstrictus (Coleoptera: Curculionidae): a new pest of canola in northeastern North America. The Canadian Entomologist 133 (5), 709-711.

Carcamo, H.A., Dosdall, L.M., Dolinski, M., Olfert, O. \& Byers, J.R. (2001) The cabbage seedpod weevil, Ceutorhynchus obstrictus (Coleoptera: Curculionidae) - a review. Journal of the Entomological Society of British Columbia 98, 201-210.

Carcamo, H.A., Dosdall, L.M., Johnson, D. \& Olfert, O. (2005) Evaluation of foliar and seed treatments for control of the cabbage seedpod weevil (Coleoptera: Curculionidae) in canola. The Canadian Entomologist 137, 476-487.

Colonnelli, E. (2004) Catalogue of Ceutorhynchinae of the world, with key to genera. 124 pp. Barcelona, Argania edito, Balmes.

Dalla Torre, K.W.V. (1898) Catalogus Hymenopterorum hucusque descriptorum systematicus et synonymicus. V. Chalcididae et Proctotrupidae. 598 pp. Leipzig.

De Clerck-Floate, R.A. \& Schwarzlaender, M. (2002) Cynoglossum officinale (L.), Houndstongue (Boraginaceae). pp. 337343 in Mason, P.G. \& Huber, J.T. (Eds) Biological control programmes in Canada 1981-2000. Wallingford, Oxon, CABI Publishing.

Dieckmann, L. (1972) Beiträge zur Insektenfauna der DDR: Coleoptera - Curculionidae: Ceutorhynchinae. Beiträge zur Entomologie 22 (1/2), 3-128.

Dosdall, L.M., Moisey, D., Carcamo, H.A. \& Dunn, R. (2001) Cabbage seedpod weevil fact sheet. Alberta Agriculture, Food and Rural Development Agdex 622-21, 1-4.

Dosdall, L.M., Weiss, R.M., Olfert, O. \& Carcamo, H.A. (2002) Temporal and geographical distribution patterns of the cabbage seedpod weevil (Coleoptera: Curculionidae) in canola. The Canadian Entomologist 134, 403-418.

Förster, A. (1878) Kleine Monographien parasitischer Hymenopteren. Verhandlungen des naturhistorischen Vereines der preussischen Rheinlande und Westphalens 35, 42-82.

Gibson, G.A.P. \& Baur, H. (2005) Mesopolobus trasullus (Walker, 1839), a valid species and senior synonym of Mesopolobus 
roseni Graham, 1984 (Hymenoptera: Chalcidoidea: Pteromalidae). Entomologist's Gazette 56, 129-132.

Gibson, G.A.P., Huber, J.T. \& Woolley, J.R. (1997) Annotated keys to the genera of Nearctic Chalcidoidea (Hymenoptera). 772 pp. Ottawa, NRC Research Press.

Gibson, G.A.P., Baur, H., Ulmer, B., Dosdall, L. \& Muller, F.J. (2005) On the misidentification of the chalcid (Hymenoptera: Chalcidoidea) parasitoids of the cabbage seedpod weevil (Coleoptera: Curculionidae) in North America. The Canadian Entomologist 137, 381-403.

Gibson, G.A.P., Gillespie, D.R. \& Dosdall, L. (2006) The species of Chalcidoidea (Hymenoptera) introduced to North America for biological control of the cabbage seedpod weevil, and the first recovery of Stenomalina gracilis (Chalcidoidea: Pteromalidae). The Canadian Entomologist 138, 285-291.

Goulet, H. \& Huber, J.T. (1993) Hymenoptera of the world: an identification guide to families. 660 pp. Ottawa, Ontario, Research Branch Agriculture Canada.

Graham, M.W.R. (1957) A revision of the Walker types of Pteromalidae (Hym., Chalcidoidea). Part 3 (including descriptions of new genera and species). Entomologist's Monthly Magazine 93, 217-236.

Graham, M.W.R. (1969) The Pteromalidae of NorthWestern Europe (Hymenoptera: Chalcidoidea). Bulletin of the British Museum (Natural History) Entomology (Suppl. 16), 1-908.

Graham, M.W.R. (1984) New Chalcidoidea (Insecta: Hymenoptera) mainly from France, including several species of Eurytoma and Pteromalus associated with Euphorbia. Journal of Natural History 18, 495-520.

Howarth, F.G. (1991) Environmental impacts of classical biological control. Annual Review of Entomology 36, 485-509.

Huber, J.T., Darbyshire, S., Bisset, J. \& Footit, R.G. (2002) Taxonomy and biological control. pp. 14-22 in Mason, P.G. \& Huber, J.T. (Eds) Biological control programmes in Canada, 1981-2000. Wallingford, Oxon, CABI Publishing.

Julien, M.H. \& Griffiths, M.W. (1998) Biological control of weeds a world catalogue of agents and their target weeds. $223 \mathrm{pp}$. Wallingford, Oxon, CABI Publishing.

Klander, B. (2001) Die Rüsselkäfer der Unterfamilie Ceutorhynchinae und deren parasitoide auf Winterraps und begleitenden Unkräutern in Schleswig-Holstein. MSc thesis, Zoologisches Institut der Christian-AlbrechtsUniversität zu Kiel, Department of Ecology, Kiel, Germany.

Knutson, L. \& Murphy, W.L. (1988) Systematics: relevance, resources, services, and management. A bibliography. Association of Systematics Collections (Suppl. 1), Washington, DC.

Kuhlmann, U., Dosdall, L.M. \& Mason, P.G. (2002) Ceutorhynchus obstrictus (Marsham), cabbage seedpod weevil (Coleoptera: Curculionidae). pp. 52-58 in Mason, P.G. \& Huber, J.T. (Eds) Biological control programmes in Canada, 1981-2000. Wallingford, Oxon, CABI Publishing.

Kuhlmann, U., Mason, P.G., Hinz, H.L., Blossey, B., De Clerck-Floate, R.A., Dosdall, L., McCaffrey, J.P., Schwarzlaender, M., Olfert, O., Brodeur, J., McClay, A.S. \& Wiedenmann, R.N. (2006a) Avoiding conflicts between insect and weed biological control: selection of non-target species for test list to assess host specificity of cabbage seedpod weevil parasitoids. Journal of Applied Entomology 130, 129-141.

Kuhlmann, U., Schaffner, U. \& Mason, P.G. (2006b) Selection of non-target species for host specificity testing. pp. 15-37 in Bigler, F., Babendreier, D. \& Kuhlmann, U. (Eds) Environmental impact of invertebrates for biological control of arthropods: methods and risk assessment. Wallingford, Oxon, CABI Publishing.

Louda, S.M., Pemberton, R.W., Johnson, M.T. \& Follett, P.A. (2003) Nontarget effects: the Achilles' heel of biological control? Retrospective analysis to reduce risk associated with biocontrol introductions. Annual Review of Entomology 48, 365-396.

Mason, P.G. \& Huber, J.T. (Eds) (2002) Biological control programmes in Canada, 1981-2000. 608 pp. CABI Publishing, Wallingford, UK.

Mason, P.G., Baute, T., Olfert, O. \& Roy, M. (2004) Cabbage seedpod weevil, Ceutorhynchus obstrictus (Marsham) (Coleoptera: Curculionidae) in Ontario and Quebec. Journal of the Entomological Society of Ontario 134, 107-113.

Mayr, G. (1904) Hymenopterologische Miszellen. III. Verhandlungen der Zoologisch-Botanischen Gesellschaft in Wien 54, 559-598.

McClay, A.S., Bourchier, R.S., Butts, P.A. \& Peschken, D.P. (2002a) Cirsium arvense (L.) Scopoli, Canada thistle (Asteraceae). pp. 318-330 in Mason, P.G. \& Huber, J.T. (Eds) Biological Control Programmes in Canada, 1981-2000. Wallingford, Oxon, UK, CABI Publishing.

McClay, A.S., Hinz, H.L., De Clerck-Floate, R.A. \& Peschken, D.P. (2002b) Matricaria perforata Mérat, Scentless Chamomille (Asteraceae). pp. 395-402 in Mason, P.G. \& Huber, J.T. (Eds) Biological Control Programmes in Canada, 1981-2000. Wallingford, Oxon, UK, CABI Publishing.

McLeod, J.H. (1953) Notes on the cabbage seedpod weevil, Ceutorhynchus assimilis (Payk.) (Coleoptera: Curculionidae), and its parasites. Entomological Society of British Columbia, Proc. 49, 11-18.

McLeod, J.H. (1962) Part 1 - Biological control of pests of crops, fruit trees, ornamentals, and weeds in Canada up to 1959. 216 pp. in A review of the biological control attempts against insects and weeds in Canada. Farnham, Bucks, UK, Commonwealth Agricultural Bureaux.

Murchie, A.K. \& Williams, I.H. (1998) A bibliography of the parasitoids of the cabbage seed weevil (Ceutorhynchus assimilis Payk.). IOBC wprs Bulletin 21 (5), 163-169.

Noyes, J.S. (2006) Universal Chalcidoidea Database. www.nhm. ac.uk/entomology/chalcidoids/index.html. last accessed 20 April 2006.

Rondani, C. (1872) Sopra alcuni vesparii parassiti. Note. Bullettino della Società Entomologica Italiana 4 (2), 201-208.

Rosen, H.V. (1961) Zur Kenntnis des Pteromaliden-Genus Mesopolobus Westwood 1833 (Hym., Chalc.) VII. Ergänzungen und Berichtigungen $\mathrm{zu}$ den bisher erschienenen 6 Beiträgen. Entomologisk Tidskrift 82 (1-2), 1-48.

Simberloff, D. (2005). The politics of assessing risk for biological invasions: the USA as a case study. Trends in Ecology and Evolution 20, 216-222.

Simberloff, D. \& Stiling, P. (1996) How risky is biological control? Ecology 77, 1965-1974.

Stiling, P. (2004) Biological control not on target. Biological Invasions 6, 151-159.

Stiling, P. \& Simberloff, D. (2000) The frequency and strength of nontarget effects of invertebrate biological control agents of plant pests and weeds. pp. 31-43 in Follet, P.A. \& Duan, J.J. (Eds) Nontarget effects of biological control. Norwell/USA, Kluwer Academic Publishers.

Thomas, M.B. \& Willis, A.J. (1998) Biocontrol - risky but necessary? Trends in Ecology and Evolution 13, 325-329. 
Thomson, C.G. (1878) Hymenoptera Scandinaviae. Tom. V. Pteromalus (Svederus) continuatio. Lund, 307 pp. +1 pl.

Van Driesche, R.G. \& Reardon, R. (2004) Assessing host ranges for parasitoids and predators used for classical biological control: A guide to best practice. 234 pp. Forest Health Technology Enterprise Team, USDA-Forest Service, Morgantown, WV, USA.

Vidal, S. (2003) Identification of Hymenopterous parasitoids associated with oilseed rape pests. pp. 161-179 in Alford, D.V. (Ed.) Biocontrol of oilseed rape pests. Oxford, Blackwell Science.

Walker, F. (1834) Monographia Chalciditum (continued from p. 309). Entomological Magazine 2, 340-369.

Walker, F. (1839) Monographia Chalciditum. London 1, 333 pp.

Walker, F. (1845) Characters of undescribed species of British Chalcidites. Proceedings of the Linnean Society of London (Zoology) 1 (24), 261-263.
Walker, F. (1848) List of the specimens of Hymenopterous insects in the collection of the British Museum, part 2. E. Newman, London, iv +237 pp.

Walker, F. (1874) Descriptions of Amurland Chalcidiae. Cistula Entomologica 1, 311-321.

Williams, I.H. (2003) Parasitoids of cabbage seed weevil. pp. 97112 in Alford, D.V. (Ed.) Biocontrol of oilseed rape pests. Oxford, Blackwell Science.

Wright, M.G., Hoffmann, M.P., Kuhar, T.P., Gardner, J. \& Pitcher, S.A. (2005) Evaluating risks of biological control introductions: A probabilistic risk-assessment approach. Biological Control 35 (3), 338-347.

(Accepted 19 December 2006) (C) 2007 Cambridge University Press 